\title{
Evaluasi Sistem Informasi Human Resources Management Systems PT MMC Metal Fabrication Bekasi
}

\author{
Aditya Ramadhani Zulfa ${ }^{[1]}$, Petrus Dwi Ananto Pamungkas ${ }^{[2]}$ \\ Prodi Sistem Informasi; Universitas Bina Insani; Jl. Siliwangi No 6 Rawa Panjang Bekasi Barat ${ }^{[1]}$ \\ Prodi Sekretari; STIKS Tarakanita; Kompleks Billy \& Moon, Pondok Kelapa, Jakarta Timur ${ }^{[2]}$ \\ adirazu@gmail.com ${ }^{[1]}$, petrusananto@gmail.com ${ }^{[2]}$
}

\begin{abstract}
The HRMS (Human Resources Management System) Information System functions to process employee data related to the Human Resources Department. After running this HRMS Information System for several years, the leadership of PT MMC Metal Fabrication wanted to find out the extent of maturity and the shortcomings found in the HRMS Information System. To find out the extent of maturity of the HRMS Information System, an HRMS Information System Evaluation is needed. To adjust the standards in Indonesia, Information System Evaluation is made using the Index KAMI (Information Security). Index KAMI is an Information System Evaluation framework adopted from ISO 27001 that has been adjusted to the standards in Indonesia. The results of this study can provide the maturity level of the HRMS Information System along with the findings.
\end{abstract}

Keywords- Index KAMI; Information System Evaluation; Human Resources Management System

\begin{abstract}
Abstrak- Sistem Informasi HRMS (Human Resources Management System) berfungsi untuk mengolah data karyawan yang berhubungan dengan bagian Human Resources. Setelah berjalannya Sistem Informasi HRMS ini selama beberapa tahun, pimpinan dari PT MMC Metal Fabrication ingin mengetahui sejauh mana tingkat kematangan dan apa saja kekurangan yang terdapat pada Sistem Informasi HRMS tersebut. Untuk mengetahui sejauh manakah tingkat kematangan Sistem Informasi HRMS maka dibutuhkan Evaluasi terhadap Sistem Informasi HRMS. Untuk menyesuaikan standar yang ada di Indonesia maka Evaluasi Sistem Informasi dibuat dengan menggunakan Indeks KAMI (Kemanan Informasi). Indeks KAMI merupakan framework Evaluasi Sistem Informasi yang diadopsi dari ISO 27001 yang telah disesuaikan dengan standar yang ada di Indonesia. Hasil penelitian ini dapat memberi tahukan tingkat kematangan dari Sistem Informasi HRMS beserta temuan-temuan yang ada.
\end{abstract}

Kata Kunci- Indeks KAMI; Evaluasi Sistem Informasi; Human Resources Management System

\section{PENDAHULUAN}

Sistem Informasi telah menjadi bagian penting dalam membantu kegiatan manusia sehari hari, terutama dalam meningkatkan kualitas pekerjaan yang dilakukannya. Dengan meningkatnya kualitas pekerjaan maka secara otomatis perusahaan tempat bekerja juga akan meningkat. Oleh karena itu banyak perusahaan telah menggunakan Sistem Informasi sebagai alat bantu. Tetapi Sistem Informasi tersebut perlu diawasi dalam penggunaannya. Salah satu yang perlu diawasi dalam penggunaan Sistem Informasi adalah tingkat kematangannya sehingga diketahui kekurangan apa saja yang terdapat di dalam sistem informasi yang telah berjalan selama ini dan perusahaan dapat membuat rancangan pengembangan dengan tepat.

PT MMC Metal Fabrication didirikan pada tahun 1997 di Indonesia sebagai anak perusahaan penuh dari Mitsubishi Materials Corporation untuk memasok produk-produk fabrication kepada pelanggan di seluruh dunia dengan kualitas tinggi dan harga yang wajar. PT MMC Metal Fabrication telah memfokuskan fabrication bahan stainless steel atau bahan kelas yang lebih tinggi, seperti bahan dasar paduan $\mathrm{Ni}$, Titanium dan lain sebagainya, yang dikenal sebagai exotic materials. Sebagai salah satu perusahaan yang sudah menerapkan Sistem Informasi maka PT MMC Metal Fabrication memiliki beberapa Sistem Informasi antara lain Sistem Informasi Human Resources Management Systems, Sistem Informasi Produksi, Sistem Informasi Akuntansi, dan Sistem Informasi Kawasan Berikat.

Salah satu Sistem Informasi yang cukup lama berjalan pada PT MMC Metal Fabrication adalah Sistem Informasi Human Resources Management Systems. Sampai dengan saat ini Sistem Informasi tersebut belum pernah dilakukan Evaluasi sehingga belum diketahui apakah Sistem Informasi tersebut masih layak digunakan atau perlu adanya perbaikan.

"Evaluasi merupakan kegiatan identifikasi untuk melihat apakah suatu program yang telah direncanakan telah tercapai atau belum, berharga atau tidak, serta dapat pula digunakan untuk melihat tingkat efisiensi pelaksanaannya" [1]. "Sistem Informasi (SI) adalah kombinasi dari orang-orang, perangkat keras, perangkat lunak, jaringan komunikasi, sumber daya data, dan kebijakan serta prosedur dalam menyimpan, mendapatkan kembali, mengubah, dan menyebarkan informasi dalam suatu organisasi" [2].

Maka dapat ditarik kesimpulan bahwa Evaluasi Sistem Informasi yaitu proses pengecekan terhadap data terkait yang 
telah dikumpulkan untuk mengetahui sejauh mana kualitas dari sebuah Sistem Informasi yang telah berjalan dan diharapkan hasil akhir dari pengecekan tersebut dapat memberikan solusi untuk meningkatkan efektif dan efisiensi sistem informasi berbasis komputer tersebut.

Indeks KAMI (Keamanan Informasi) merupakan aplikasi yang digunakan sebagai alat bantu untuk menganalisa dan mengevaluasi tingkat kesiapan (kelengkapan dan kematangan) penerapan keamanan informasi di sebuah organisasi sesuai dengan kriteria pada SNI ISO/IEC 27001 [3], yaitu: (a) Tata Kelola, (b) Pengelolaan Risiko, (c) Kerangka Kerja, (d) Pengelolaan Aset, dan (e) Aspek Teknologi.

\section{AREA YANG DIEVALUASI INDEKS KAMI}

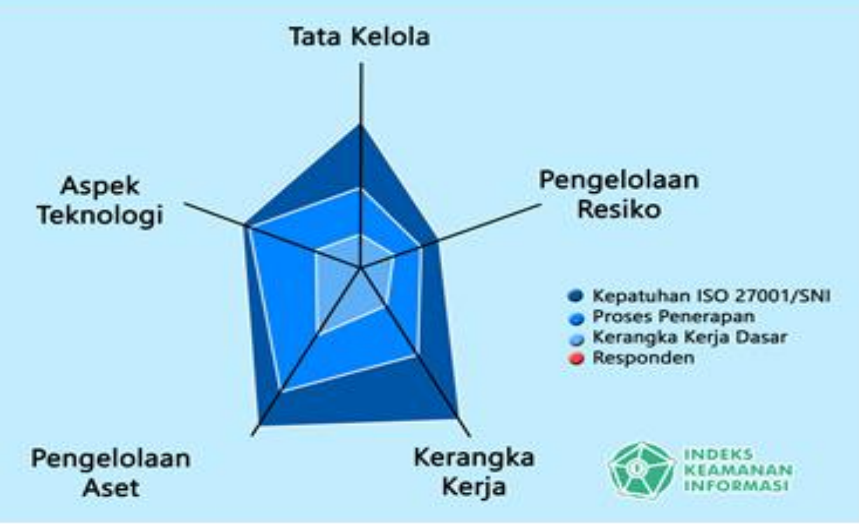

Sumber: https://bssn.go.id/indeks-kami/ (2019)

\section{Gambar 1. Area Evaluasi Indeks KAMI}

Dalam penggunaan Indeks KAMI pertanyaan dikelompokkan untuk 2 keperluan. Pertama, pertanyaan dikategorikan berdasarkan tingkat kesiapan penerapan pengamanan sesuai dengan kelengkapan kontrol yang diminta oleh standar ISO/IEC 27001:2013. Dalam pengelompokan ini responden diminta untuk memberi tanggapan mulai dari area yang terkait dengan bentuk kerangka kerja dasar keamanan informasi (pertanyaan diberi label "1"), efektifitas dan konsistensi penerapannya (label "2"), sampai dengan kemampuan untuk selalu meningkatkan kinerja keamanan informasi (label "3"). Tingkat terakhir ini sesuai dengan kesiapan minimum yang diprasyaratkan oleh proses sertifikasi standar ISO/IEC 27001:2013.

Setiap jawaban diberikan skor yang nantinya dikonsolidasi untuk menghasilkan angka indeks sekaligus digunakan untuk menampilkan hasil evaluasi dalam dashboard di akhir proses ini. Skor yang diberikan untuk jawaban pertanyaan sesuai tingkat kematangannya mengacu kepada:

TABEL 1. Skor Kategori Pengamanan Berdasarkan Status Pengamanan

\begin{tabular}{|c|c|c|c|}
\hline & 1 & 2 & 3 \\
\hline Tidak Dilakukan & 0 & 0 & 0 \\
\hline Dalam Perencanaan & 1 & 2 & 3 \\
\hline Dalam Penerapan atau Diterapkan Sebagian & 2 & 4 & 6 \\
\hline Diterapkan secara menyeluruh & 3 & 6 & 9 \\
\hline
\end{tabular}

Sumber: Indeks KAMI Versi 3.1 (2019)
Hasil dari penjumlahan skor untuk masing-masing area ditampilkan dalam diagram radar dengan latar belakang area untuk tingkat maksimal kematangan $1 \mathrm{~s} / \mathrm{d} 3$. Dalam diagram ini bisa dilihat perbandingan antara kondisi kesiapan sebagai hasil dari proses evaluasi dengan acuan tingkat kematangan yang ada.

Dengan membaca diagram ini, pimpinan instansi dapat melihat kebutuhan pembenahan yang diperlukan dan korelasi antara berbagai area penerapan keamanan informasi. Adapun korelasi antara Kategori Sistem Elektronik dengan Status Kesiapan didefinisikan melalui tabel berikut:

TABEL 2. Status Kesiapan Berdasarkan Kategori Sistem Elektronik

\begin{tabular}{|c|c|c|c|c|}
\hline \multicolumn{2}{|c|}{ Rendah } & \multicolumn{2}{|c|}{ Skor Akhir } & \\
\hline \multirow{4}{*}{10} & \multirow{4}{*}{15} & 0 & 174 & Tidak Layak \\
\hline & & 175 & 312 & Perlu Perbaikan \\
\hline & & 313 & 535 & Cukup \\
\hline & & 536 & 645 & Baik \\
\hline \multicolumn{2}{|c|}{ Tinggi } & \multicolumn{2}{|c|}{ Skor Akhir } & \\
\hline \multirow{4}{*}{16} & \multirow{4}{*}{34} & 0 & 272 & Tidak Layak \\
\hline & & 273 & 455 & Perlu Perbaikan \\
\hline & & 274 & 583 & Cukup \\
\hline & & 584 & 645 & Baik \\
\hline \multicolumn{2}{|c|}{ Strategis } & \multicolumn{2}{|c|}{ Skor Akhir } & \\
\hline \multirow{4}{*}{35} & \multirow{4}{*}{50} & 0 & 333 & Tidak Layak \\
\hline & & 334 & 535 & Perlu Perbaikan \\
\hline & & 536 & 609 & Cukup \\
\hline & & 610 & 645 & Baik \\
\hline
\end{tabular}

Sumber: Indeks KAMI Versi 3.1 (2019)

Pengelompokan kedua dilakukan berdasarkan tingkat kematangan penerapan pengamanan dengan kategorisasi yang mengacu kepada tingkatan kematangan yang digunakan oleh keangka kerja COBIT atau CMMI. Tingkat kematangan ini nantinya akan digunakan sebagai alat untuk melaporkan pemetaan dan pemberian peringkat kesiapan keamanan informasi di Kementerian/Lembaga.

Untuk keperluan Indeks KAMI, tingkat kematangan tersebut didefinisikan sebagai:

a. Tingkat I - Kondisi Awal

b. Tingkat II - Penerapan Kerangka Kerja Dasar

c. Tingkat III - Terdefinisi dan Konsisten

d. Tingkat IV - Terkelola dan Terukur

e. Tingkat V - Optimal

Untuk membantu memberikan uraian yang lebih detil, tingkatan ini ditambah dengan tingkatan antara I+, II+, III+, dan IV+, sehingga total terdapat 9 tingkatan kematangan. Sebagai awal, semua responden akan diberikan kategori kematangan Tingkat I. Sebagai padanan terhadap standar ISO/IEC 27001:2013, tingkat kematangan yang diharapkan untuk ambang batas minimum kesiapan sertifikasi adalah Tingkat III+. 


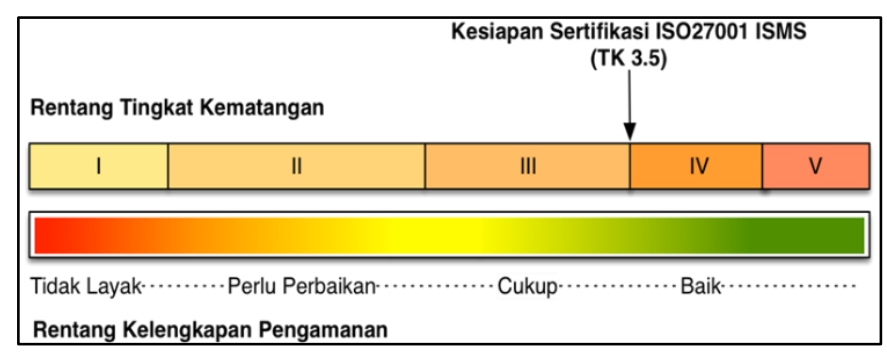

Sumber: Indeks KAMI Versi 3.1 (2019)

Gambar 2. Rentang Tingkat Kematangan dan Kelengkapan Pengamanan

Dalam penggunaan kuesioner, kuesioner yang digunakan diperoleh dari framework Indeks KAMI (Keamanan Informasi) dengan total 141 pertanyaan yang lalu dikonversi ke dalam bentuk kuesioner berbasis website agar dapat memudahkan responden dalam menjawab pertanyaanpertanyaan yang ada.

TABEL 3. Kuesioner Tata Kelola Keamanan Informasi

\begin{tabular}{|c|c|c|c|c|c|}
\hline \multirow{2}{*}{ No. } & \multirow{2}{*}{ Pertanyaan } & \multicolumn{4}{|c|}{ Pilihan Jawaban } \\
\hline & & $\mathbf{0}$ & 1 & 2 & 3 \\
\hline \# & Fungsi/Instansi Keamanan Inf & $\operatorname{mas}$ & & & \\
\hline 2.1 & $\begin{array}{l}\text { Apakah pimpinan Instansi anda secara } \\
\text { prinsip dan resmi bertanggungjawab terhadap } \\
\text { pelaksanaan program keamanan informasi } \\
\text { (misal yang tercantum dalam ITSP), } \\
\text { termasuk penetapan kebijakan terkait? }\end{array}$ & & & & \\
\hline 2.2 & $\begin{array}{l}\text { Apakah Instansi anda memiliki fungsi atau } \\
\text { bagian yang secara spesifik mempunyai tugas } \\
\text { dan tanggungjawab mengelola keamanan } \\
\text { informasi dan menjaga kepatuhannya? }\end{array}$ & & & & \\
\hline 2.3 & $\begin{array}{c}\text { Apakah pejabat/petugas pelaksana } \\
\text { pengamanan informasi mempunyai } \\
\text { wewenang yang sesuai untuk menerapkan } \\
\text { dan menjamin kepatuhan program keamanan } \\
\text { informasi? }\end{array}$ & & & & \\
\hline 2.4 & $\begin{array}{c}\text { Apakah penanggungjawab pelaksanaan } \\
\text { pengamanan informasi diberikan alokasi } \\
\text { sumber daya yang sesuai untuk mengelola } \\
\text { dan menjamin kepatuhan program keamanan } \\
\text { informasi? }\end{array}$ & & & & \\
\hline 2.5 & $\begin{array}{l}\text { Apakah peran pelaksana pengamanan } \\
\text { informasi yang mencakup semua keperluan } \\
\text { dipetakan dengan lengkap, termasuk } \\
\text { kebutuhan audit internal dan persyaratan } \\
\text { segregasi kewenangan? }\end{array}$ & & & & \\
\hline 2.6 & $\begin{array}{l}\text { Apakah Instansi anda sudah mendefinisikan } \\
\text { persyaratan/standar kompetensi dan keahlian } \\
\text { pelaksana pengelolaan keamanan informasi? }\end{array}$ & & & & \\
\hline 2.7 & $\begin{array}{l}\text { Apakah semua pelaksana pengamanan } \\
\text { informasi di Instansi anda memiliki } \\
\text { kompetensi dan keahlian yang memadai } \\
\text { sesuai persyaratan/standar yang berlaku? }\end{array}$ & & & & \\
\hline 2.8 & $\begin{array}{l}\text { Apakah instansi anda sudah menerapkan } \\
\text { program sosialisasi dan peningkatan } \\
\text { pemahaman untuk keamanan informasi, } \\
\text { termasuk kepentingan kepatuhannya bagi } \\
\text { semua pihak yang terkait? }\end{array}$ & & & & \\
\hline 2.9 & $\begin{array}{l}\text { Apakah Instansi anda menerapkan program } \\
\text { peningkatan kompetensi dan keahlian untuk } \\
\text { pejabat dan petugas pelaksana pengelolaan } \\
\text { keamanan informasi? }\end{array}$ & & & & \\
\hline 2.10 & $\begin{array}{c}\text { Apakah instansi anda sudah } \\
\text { mengintegrasikan keperluan/persyaratan } \\
\text { keamanan informasi dalam proses kerja yang }\end{array}$ & & & & \\
\hline
\end{tabular}

\begin{tabular}{|c|c|c|c|c|c|}
\hline \multirow{2}{*}{ No. } & \multirow{2}{*}{ Pertanyaan } & \multicolumn{4}{|c|}{ Pilihan Jawaban } \\
\hline & & $\mathbf{0}$ & 1 & 2 & 3 \\
\hline & ada? & & & & \\
\hline 2.11 & $\begin{array}{l}\text { Apakah instansi anda sudah } \\
\text { mengidentifikasikan data pribadi yang } \\
\text { digunakan dalam proses kerja dan } \\
\text { menerapkan pengamanan sesuai dengan } \\
\text { peraturan perundangan yang berlaku? }\end{array}$ & & & & \\
\hline 2.12 & $\begin{array}{l}\text { Apakah tanggungjawab pengelolaan } \\
\text { keamanan informasi mencakup koordinasi } \\
\text { dengan pihak pengelola/pengguna aset } \\
\text { informasi internal dan eksternal maupun } \\
\text { pihak lain yang berkepentingan, untuk } \\
\text { mengidentifikasikan persyaratan/kebutuhan } \\
\text { pengamanan (misal: pertukaran informasi } \\
\text { atau kerjasama yang melibatkan informasi } \\
\text { penting) dan menyelesaikan permasalahan } \\
\text { yang ada? }\end{array}$ & & & & \\
\hline 2.13 & $\begin{array}{l}\text { Apakah pengelola keamanan informasi } \\
\text { secara proaktif berkoordinasi dengan satker } \\
\text { terkait (SDM, Legal/Hukum, Umum, } \\
\text { Keuangan dll) dan pihak eksternal yang } \\
\text { berkepentingan (misal: regulator, aparat } \\
\text { keamanan) untuk menerapkan dan menjamin } \\
\text { kepatuhan pengamanan informasi terkait } \\
\text { proses kerja yang melibatkan berbagai pihak? }\end{array}$ & & & & \\
\hline 2.14 & $\begin{array}{l}\text { Apakah tanggungjawab untuk memutuskan, } \\
\text { merancang, melaksanakan dan mengelola } \\
\text { langkah kelangsungan layanan TIK (business } \\
\text { continuity dan disaster recovery plans) sudah } \\
\text { didefinisikan dan dialokasikan? }\end{array}$ & & & & \\
\hline 2.15 & $\begin{array}{l}\text { Apakah penanggungjawab pengelolaan } \\
\text { keamanan informasi melaporkan kondisi, } \\
\text { kinerja/efektifitas dan kepatuhan program } \\
\text { keamanan informasi kepada pimpinan } \\
\text { Instansi secara rutin dan resmi? }\end{array}$ & & & & \\
\hline 2.16 & $\begin{array}{l}\text { Apakah kondisi dan permasalahan keamanan } \\
\text { informasi di Instansi anda menjadi } \\
\text { konsideran atau bagian dari proses } \\
\text { pengambilan keputusan strategis di Instansi } \\
\text { anda? } \\
\end{array}$ & & & & \\
\hline 2.17 & $\begin{array}{l}\text { Apakah pimpinan satuan kerja di Instansi } \\
\text { anda menerapkan program khusus untuk } \\
\text { mematuhi tujuan dan sasaran kepatuhan } \\
\text { pengamanan informasi, khususnya yang } \\
\text { mencakup aset informasi yang menjadi } \\
\text { tanggungjawabnya? }\end{array}$ & & & & \\
\hline 2.18 & $\begin{array}{c}\text { Apakah Instansi anda sudah mendefinisikan } \\
\text { metrik, paramater dan proses pengukuran } \\
\text { kinerja pengelolaan keamanan informasi } \\
\text { yang mencakup mekanisme, waktu } \\
\text { pengukuran, pelaksananya, pemantauannya } \\
\text { dan eskalasi pelaporannya? }\end{array}$ & & & & \\
\hline 2.19 & $\begin{array}{l}\text { Apakah Instansi anda sudah menerapkan } \\
\text { program penilaian kinerja pengelolaan } \\
\text { keamanan informasi bagi individu (pejabat \& } \\
\text { petugas) pelaksananya? }\end{array}$ & & & & \\
\hline 2.20 & $\begin{array}{c}\text { Apakah Instansi anda sudah menerapkan } \\
\text { target dan sasaran pengelolaan keamanan } \\
\text { informasi untuk berbagai area yang relevan, } \\
\text { mengevaluasi pencapaiannya secara rutin, } \\
\text { menerapkan langkah perbaikan untuk } \\
\text { mencapai sasaran yang ada, termasuk } \\
\text { pelaporan statusnya kepada pimpinan } \\
\text { Instansi? }\end{array}$ & & & & \\
\hline 2.21 & $\begin{array}{c}\text { Apakah Instansi anda sudah mengidentifikasi } \\
\text { legislasi, perangkat hukum dan standar } \\
\text { lainnya terkait keamanan informasi yang } \\
\text { harus dipatuhi dan menganalisa tingkat } \\
\text { kepatuhannya? }\end{array}$ & & & & \\
\hline 2.22 & Apakah Instansi anda sudah mendefinisikan & & & & \\
\hline
\end{tabular}




\begin{tabular}{|l|l|l|l|l|l|}
\hline \multirow{2}{*}{ No. } & \multicolumn{1}{|c|}{ Pertanyaan } & \multicolumn{4}{|c|}{ Pilihan Jawaban } \\
\cline { 3 - 6 } & $\begin{array}{l}\text { kebijakan dan langkah penanggulangan } \\
\text { insiden keamanan informasi yang } \\
\text { menyangkut pelanggaran hukum (pidana dan } \\
\text { perdata)? }\end{array}$ & & & & \\
\hline
\end{tabular}

Sumber: Indeks KAMI Versi 3.1 (2019)

$$
\text { Ket: } \begin{aligned}
0 & =\text { Tidak Dilakukan } \\
1 & =\text { Dalam Perencanaan } \\
2 & =\text { Dalam Penerapan } / \text { Diterapkan Sebagian } \\
3 & =\text { Diterapkan Secara Menyeluruh }
\end{aligned}
$$

Tabel 3 merupakan contoh kuesioner yang diperoleh dari framework Indeks KAMI (Keamanan Informasi) yang akan digunakan untuk melakukan Evaluasi Sistem Informasi terhadap Sistem Informasi Human Resources Management Systems.

Dinas Komunikasi dan Informatika Kota Batu memerlukan evaluasi terhadap keamanan informasi. Sebagai penyedia informasi, Dinas Komunikasi dan Informatika Kota Batu memerlukan evaluasi tingkat keamanan informasi. Pada penelitian ini evaluasi dilakukan dengan instrumen kuesioner berdasar pada Indeks Kemananan Informasi (KAMI) untuk melihat hasil kelengkapan dan kematangan keamanan informasi pada 5 area, tata kelola, pengelolaan risiko, kerangka kerja, pengelolaan aset, dan teknolongi. Dari hasil evaluasi diketahui bahwa untuk tingkat kelengkapan mendapatkan skor 203 dan rata-rata tingkat kematangan setiap area keamanan informasi berada pada Level I sampai Level I+. Hal ini menyatakan bahwa Dinas Komunikasi dan Informatika Kota Batu dinyatakan tidak layak untuk melakukan sertifikasi ISO 27001. Rekomendasi didapatkan dari hasil perbandingan antara Indeks KAMI dengan kontrol pada ISO 27001. Rekomendasi yang dapat diberikan kepada Dinas Komunikasi dan Informatika Kota Batu salah satunya harus membuat kebijakan terkait keamanan informasi berdasarkan kontrol objektif A.5.1 pada ISO 27001 [4].

Perkembangan sistem informasi yang cepat telah membuat perubahan hampir di semua bidang kegiatan manusia, termasuk pengelolaan perpustakaan di perguruan tinggi. Kehadiran perangkat lunak (aplikasi) perpustakaan Senayan Library Management System (SLiMS) yang handal ternyata sangat membantu para penanggung jawab perpustakaan di perguruan tinggi dalam mengelola perpustakaan, mulai dari input data, pencarian sampai dengan transaksi peminjaman dan pengembalian koleksi pustaka. Banyaknya penggunaan aplikasi SLiMS diharapkan bukan saja karena sifatnya yang Open Source Software atau bebas penggunaan dan lisensi melainkan juga dikarenakan kualitas aplikasi yang baik. Dengan menggunakan aspek Functionality (Fungsionalitas), Reliability (Kehandalan), Usability (Kebergunaan), Efficiency (Efisiensi), Maintainability (Pemeliharaan), dan Portability (Portabilitas) yang ada dalam standar ISO 9126 dimungkinkan untuk dilakukan pengujian kualitas aplikasi SLiMS. Adapun metode pengumpulan data yang digunakan adalah penggunaan Google Forms dalam membuat dan menyebarkan kuesioner serta wawancara kepada beberapa penanggung jawab perpustakaan perguruan tinggi. Hasil pengumpulan data tersebut untuk kemudian diolah hingga menghasilkan informasi bahwa aplikasi SLiMS termasuk dalam kategori SANGAT BAIK. Hal ini berarti bahwa aplikasi SLiMS yang selama ini telah digunakan oleh beberapa penanggung jawab perpustakaan perguruan tinggi ternyata memiliki kualitas sangat baik dan sangat membantu dalam pengelolaan perpustakaan yang ada di perguruan tinggi [5].

Perguruan Tinggi, misi mencari, menemukan, dan menyebarluaskan kebenaran ilmiah tersebut dapat diwujudkan apabila perguruan tinggi di kelola berdasarkan suatu Tata kelola perguruan tinggi yang baik (Good University Governance). Pengelolaan Informasi merupakan salah satu aspek dalam Good University Governance, termasuk kualitas dan keamanan pengelolaan informasi. Salah satu upaya yang dapat dilakukan untuk meningkatkan kualitas dari keamanan informasi, kementrian Kominfo membuat alat bantu untuk mengukur tingkat kematangan dan kelengkapan dalam keamanan informasi yang disebut dengan Indeks Keamanan Informasi (KAMI). Hasil penilaian kelima area yang telah dilakukan adalah sebesar 249 dari 645 dan berada pada kategori tidak layak. Dari hasil tersebut maka dibuat rekomendasi berdasarkan kontrol ISO 27002:2013 untuk pertanyaan-pertanyaan yang mendapat nilai kurang [6]

Penggunaan sistem informasi telah dilakukan oleh Politeknik LP3I Jakarta sejak tahun 2010, namun seiring penerapan sistem informasi tersebut timbul kendala-kendala yang sering dialami oleh penggunanya. Rata-rata pengguna mengeluhkan lambatnya proses (loading) dari sistem informasi, sehingga mengakibatkan tidak efektifnya waktu dalam penggunaan sistem informasi. Namun hal ini perlu pembuktian lebih lanjut, untuk itu penulis mencoba untuk melakukan penelitian berupa evaluasi penerapan sistem informasi pada Politeknik LP3I Jakarta dengan indikator PIECES Frame work dan hasilnya ditujukan untuk memberikan saran bagi Politeknik LP3I Jakarta dalam mengelola sistem informasi.Disamping itu, juga dianjurkan pihak Politeknik LP3I Jakarta untuk mengupgrade infrastruktur yang ada dan merubah kebijakan tentang hak akses informasi terhadap mahasiswa [7].

Pada sisi yang lain pertumbuhan hotel yang cukup pesat di Yogyakarta berpotensi menimbulkan terjadinya persaingan yang semakin ketat dan kompetitif. Penyusunan rumusan strategi perusahaan di masa yang akan datang menggunakan hasil evaluasi dari framework COBIT 4.1 dengan menggunakan 2 domain yaitu: Planning and Organizing (PO), dan Monitor and Evaluate (ME). Hasil penelitian menunjukkan bahwa Variabel Human, Organization, Technology berpengaruh positif dan signifikan terhadap Net Benefits. Berdasarkan hasil analisis diperoleh nilai $t$ hitung pada variabel Human, Organization, Technology sebesar 2.491. sehingga hipotesis penelitian pada variabel ini diterima kebenarannya. Berdasarkanhasil evaluasi tersebut,telah disusun suatu rekomendasi yang dapat dijadikan dasar untuk merumuskan strategi perusahaan secara khusus pada aspek pengelolaan teknologi informasi di Hotel Wisanti Yogyakarta [8].

Berdasarkan penelitian-penelitian tersebut dapat ditarik kesimpulan bahwa terdapat permasalahan-permasalahan yang 
dihadapi dalam penggunaan sistem informasi, untuk membuktikan masalah tersebut perlu diadakan evaluasi pada sistem informasi sehingga adanya acuan terhadap tingkat kematangan sistem informasi. Diharapkan dengan adanya evaluasi pada sistem informasi maka perusahaan atau organisasi memiliki landasan untuk melakukan perbaikan secara lebih matang dan tersusun rapi. Untuk melakukan evaluasi terhadap sistem informasi yang paling umum adalah menggunakan framework Cobit dan Indeks KAMI, terutama untuk penggunaan Indeks KAMI karena telah menggunakan acuan standar umum yang ada di Indonesia akan tetapi tetap mengacu pada ISO:27001 sehingga memiliki standar yang tepat secara umum.

\section{METODE PENELITIAN}

Metode penelitian yang digunakan dalam Evaluasi Sistem Informasi ini adalah framework Indeks KAMI (Keamanan Informasi). Alat evaluasi ini tidak ditujukan untuk menganalisis kelayakan atau efektifitas bentuk pengamanan yang ada, melainkan sebagai perangkat untuk memberikan gambaran kondisi kesiapan (kelengkapan dan kematangan) kerangka kerja keamanan informasi kepada pimpinan Instansi. Evaluasi dilakukan terhadap berbagai area yang menjadi target penerapan keamanan informasi dengan ruang lingkup pembahasan yang juga memenuhi semua aspek keamanan yang didefinisikan oleh standar ISO/IEC 27001:2013.

Pada framework Indeks KAMI terdapat beberapa kuesioner evaluasi yang digunakan agar terlaksananya pengumpulan data. Pertanyaan-pertanyaan yang ada dalam kuesioner Indeks KAMI sebaiknya dijawab semuanya. Yang perlu diperhatikan oleh responden adalah jawaban yang diberikan harus merefleksikan kondisi penerapan keamanan sistem informasi sesungguhnya. Alat evaluasi ini hanya akan memberikan nilai tambah bagi semua pihak apabila pengisiannya menggunakan asas keterbukaan dan kejujuran.

Kerangka penelitian dalam penelitian ini terdiri dari (1). Permasalahan. Permasalahan yang ada dalam PT MMC Metal Fabrication adalah mengetahui tingkat kematangan sistem informasi Human Resources Management Systems. (2). Analisis Kebutuhan. Analisis kebutuhan adalah seperti perlunya dilakukan Evaluasi Sistem Informasi dan juga pihak terkait diharuskan untuk menjawab kuesioner yang telah disediakan termasuk adanya laporan hasil evaluasi. (3). Persiapan Evaluasi Sistem Informasi. Persiapan yang dilakukan berupa mempersiapkan kuesioner dari Indeks KAMI (Keamanan Informasi) lalu dikonversi ke dalam bentuk website. (4). Pelaksanaan Evaluasi Sistem Informasi. Pelaksanaan yaitu melakukan kegiatan Evaluasi Sistem Informasi menggunakan Indeks KAMI dengan bantuan kuesioner berbasis website. (5). Hasil. Hasil yang diharapkan adalah PT MMC Metal Fabrication dapat mengetahui tingkat kematangan sistem informasi Human Resources Management Systems.

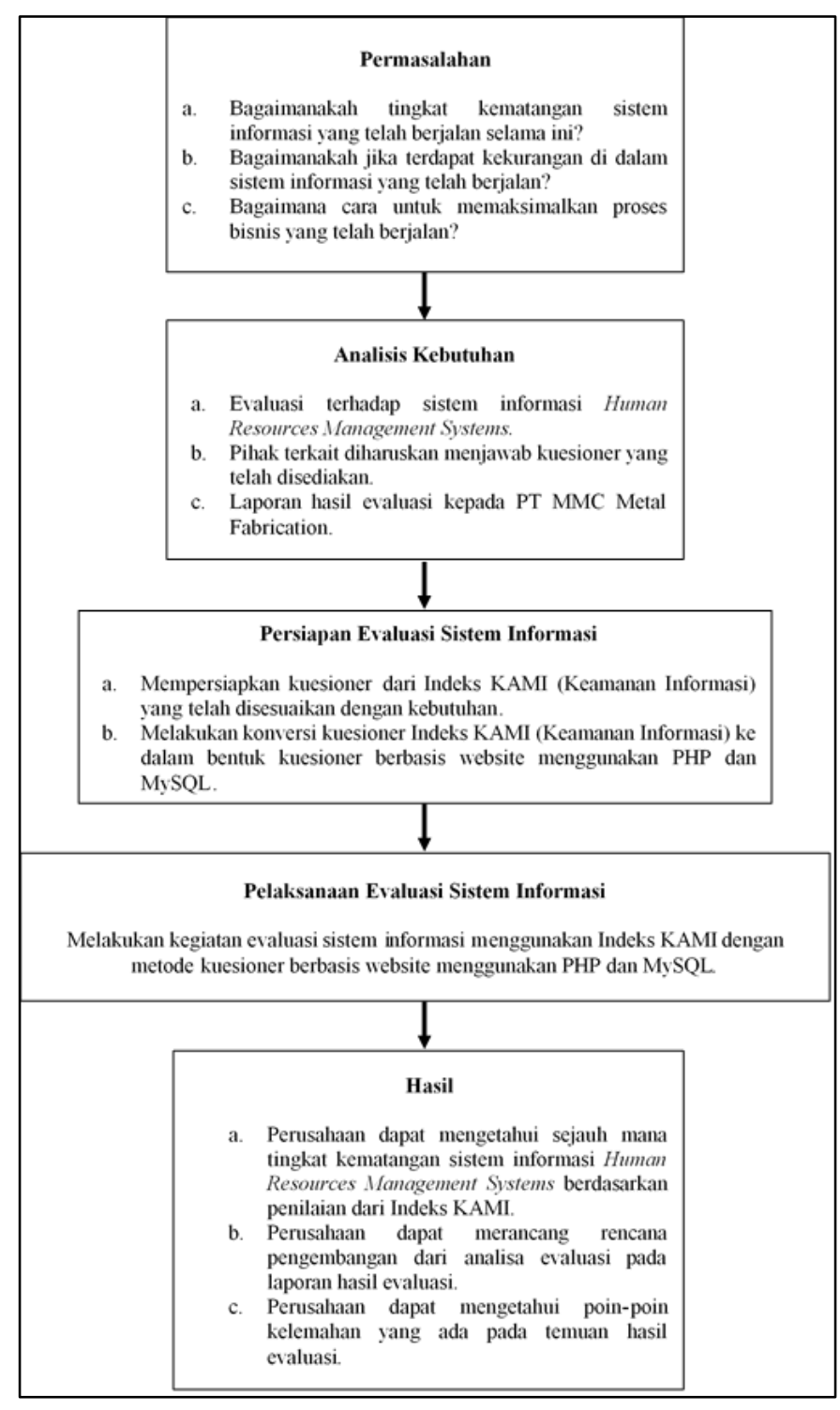

Sumber: Hasil Penelitian (2018)

Gambar 3. Kerangka Pemikiran

\section{HASIL DAN PEMBAHASAN}

\section{A. Subjek Evaluasi SI}

Subjek Evaluasi yang dipilih adalah Sistem Informasi Human Resoruces Management Systems. Sistem informasi HRMS (Human Resources Management Systems) bertujuan untuk mengelola data seluruh karyawan dan membantu meringankan tugas bagian administrasi mulai dari absensi harian hingga pada tahap penggajian.

\section{B. Analisa Evaluasi SI}

Berikut ini adalah analisa evaluasi sistem informasi Human Resources Management Systems pada PT MMC Metal Fabrication berfokus pada 2 poin yaitu:

a) Identifikasi Responden 
Dalam evaluasi sistem informasi Human Resources Management Systems ini responden yang bertanggung jawab untuk mengisi kuesioner yang telah disesuaikan berdasarkan kebutuhan dan mengacu pada framework Indeks KAMI (Keamanan Informasi) adalah perwakilan dari bagian IT (Information Technology) yang memahami ruang lingkup objek evaluasi beserta aturan-aturan terkait sehingga diharpakan dapat menjawab kuesioner dengan maksimal. Responden dalam evaluasi ini adalah pembuat dan penanggung jawab Sistem Informasi HRMS yang memahami sistem informasi Human Resources Management Systems secara keseluruhan.

\section{b) Identifikasi Risiko}

Dalam melakukan evaluasi sistem informasi Human Resources

Management Systems ini terdapat beberapa risiko yang teridentifikasi antara lain:

1) Sistem Informasi Human Resources Management Systems ini mengolah langsung data perusahaan yang bersifat sensitif dan pribadi sehingga tidak dapat dilakukan evaluasi langsung terhadap sistem informasi tersebut karena dikhawatirkan terjadinya kebocoran data perusahaan.

2) Risiko validitas data karena responden yang dapat melakukan pengisian kuesioner evaluasi sistem informasi hanyalah yang memahami sistem informasi Human Resources Management Systems secara keseluruhan yaitu pembuat dan penanggung jawab Sistem Informasi HRMS.

\section{Hasil Pengolahan Evaluasi SI}

Setelah melakukan evaluasi sistem informasi terhadap sistem informasi Human Resources Management Systems dengan menggunakan kuesioner Indeks KAMI (Keamanan Informasi) terhadap 5 area (Tata Kelola Keamanan Informasi, Pengelolaan Risiko Keamanan Informasi, Kerangka Kerja Keamanan Informasi, Pengelolaan Aset Informasi, Teknologi dan Keamanan Informasi) berdasarkan tingkat Kategori Sistem Elektronik maka diperoleh hasil sebagai berikut:

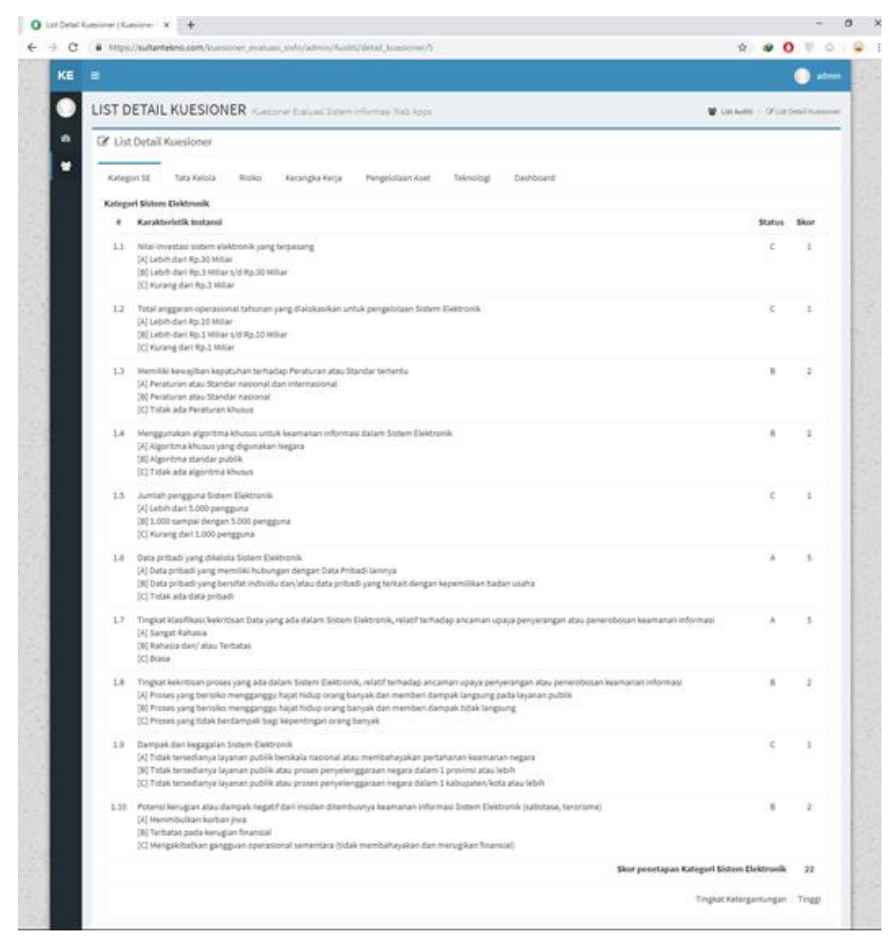

Sumber: Hasil Penelitian (2018)

Gambar 4. Halaman Jawaban Kuesioner Area Kategori Sistem Elektronik

Gambar 4 merupakan contoh halaman yang digunakan untuk mengolah hasil jawaban setiap area evaluasi yang diperoleh dari responden. Setiap halaman memiliki skor setiap area yang pada akhirnya akan menentukan Grafik Hasil Evaluasi Akhir.

\section{Temuan Hasil Evaluasi SI}

Dari hasil kuesioner yang telah diisi oleh responden terbentuk lah dashboard hasil evaluasi sehingga pihak eksekutif dapat dengan mudah memahami hasil evaluasi sistem informasi terhadap sistem informasi Human Resources Management Systems yang dapat dilihat pada gambar di bawah ini.

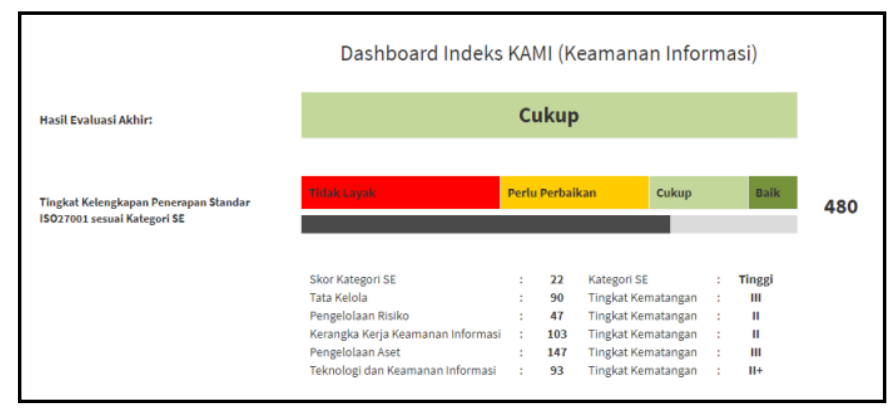

Sumber: Hasil Penelitian (2018)

Gambar 5. Dashboard Indeks KAMI (Keamanan Informasi)

Gambar 5 menunjukan hasil evaluasi berdasarkan kuesioner yang telah diisi oleh responden, dalam gambar terlihat bahwa Sistem Informasi Human Resources Management Systems memperoleh Hasil Evaluasi Akhir "Cukup" dengan total skor 480 dari 645 skor maksimal. Pada 
Kategori Sistem Elektronik memperoleh kategori "Tinggi" dengan memperoleh skor 22 dari 50 skor maksimal. Pada 5 area lain nya secara keseluruhan memperoleh tingkat kematangan terendah II dan tingkat kematangan tertinggi adalah III.

Dari dashboard yang telah diperoleh dapat diuraikan untuk mengetahui tingkat kematangan kelima area yang yang telah dinilai sebelumnya yaitu sebagai berikut:

TABEL 4. Tingkat Kematangan Kelima Area Evaluasi

\begin{tabular}{|c|c|c|c|c|c|}
\hline & $\begin{array}{c}\text { Tata } \\
\text { Kelola }\end{array}$ & $\begin{array}{c}\text { Pengelol } \\
\text { aan } \\
\text { Risiko }\end{array}$ & $\begin{array}{c}\text { Kerang } \\
\text { ka } \\
\text { Kerja }\end{array}$ & $\begin{array}{c}\text { Pengelola } \\
\text { an Aset }\end{array}$ & $\begin{array}{c}\text { Teknolo } \\
\text { gi }\end{array}$ \\
\hline \multicolumn{6}{|c|}{ Tingkat Kematangan II } \\
\hline Status & II & II & II & II & II \\
\hline \multicolumn{6}{|c|}{ Tingkat Kematangan III } \\
\hline Status & Yes & No & No & Yes & Yes \\
\hline Validitas & III & No & No & III & II+ \\
\hline \multicolumn{6}{|c|}{ Tingkat Kematangan IV } \\
\hline Status & No & No & No & No & No \\
\hline Validitas & No & No & No & No & No \\
\hline \multicolumn{6}{|c|}{ Tingkat Kematangan V } \\
\hline Status & No & No & No & No & No \\
\hline Validitas & No & No & No & No & No \\
\hline \multirow[t]{2}{*}{$\begin{array}{l}\text { Status } \\
\text { Akhir }\end{array}$} & III & II & II & III & II+ \\
\hline & 5 & 3 & 3 & 5 & 4 \\
\hline
\end{tabular}

Sumber: Hasil Penelitian (2018)

Dari tabel tingkat kematangan pada kelima area yang telah di evaluasi di atas dapat terlihat bahwa pada area tata kelola mendapat tingkat kematangan III, pada area pengelolaan risiko mendapat tingkat kematangan II, pada area kerangka kerja mendapat tingkat kematangan II, pada area pengelolaan aset mendapat tingkat kematangan III dan pada area teknologi mendapat tingkat kematangan II+.

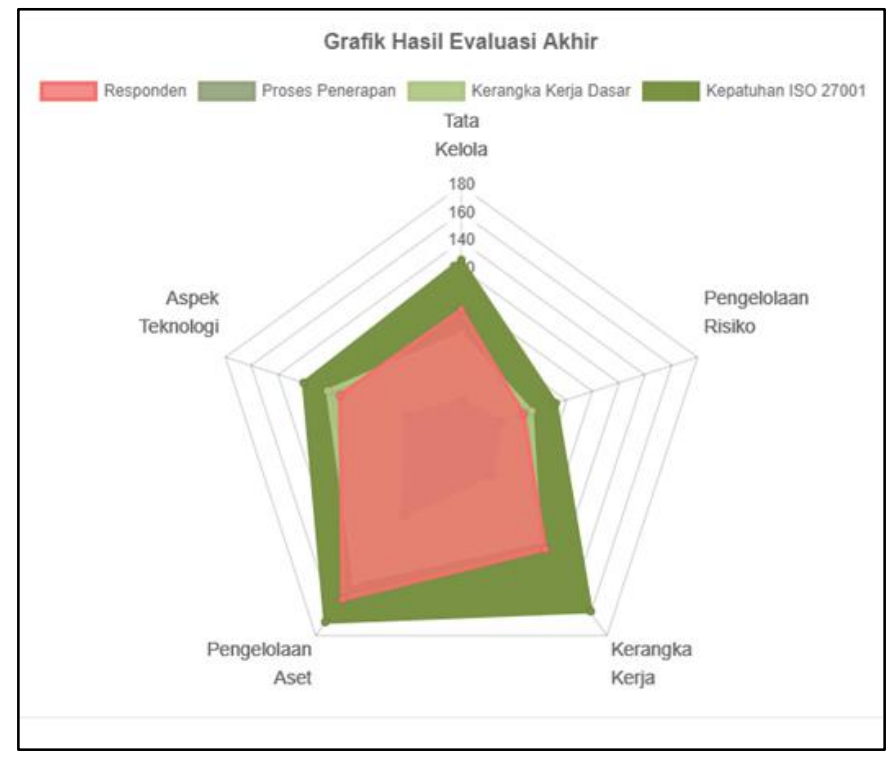

Sumber: Hasil Penelitian (2018)

\section{Gambar 6. Grafik Hasil Evaluasi Akhir}

Dengan skor 90 pada area Tata Kelola, skor 47 pada area Pengelolaan Risiko, skor 103 pada area Kerangka Kerja, skor
147 pada area Pengelolaan Aset dan skor 93 pada area Aspek Teknologi maka terbentuklah grafik radar seperti pada gambar 6 Grafik berwarna hijau tua adalah Kepatuhan ISO 27001, grafik berwarna hijau muda adalah kerangka kerja dasar atau dapat disebut juga sebagai batas minimum kesiapan sertifikasi, grafik berwarna abu-abu adalah proses penerapan dan grafik berwarna merah muda adalah grafik yang terbentuk dari hasil jawaban kuesioner oleh responden.

Dari gambar grafik di atas dapat disimpulkan bahwa secara keseluruhan Sistem Informasi Human Resources Management System sudah hampir memenuhi batas minimum kesiapan sertifikasi, hanya saja sistem informasi tersebut masih terdapat beberapa kekurangan yaitu pada bagian area pengelolaan risiko dan area aspek teknologi. Sehingga untuk memaksimalkan sistem informasi yang telah berjalan maka terbentuklah rekomendasi berdasarkan hasil evaluasi yang telah diperoleh.

\section{E. Rekomendasi Hasil Evaluasi SI}

Dari hasil pengolahan dan temuan pada Evaluasi Sistem Informasi Human Resources Management System maka terbentuklah beberapa poin rekomendasi terhadap Sistem Informasi Human Resources Management System. Agar mencapai standar kerangka kerja dasar maka direkomendasikan sebagai berikut:

\section{1) Rekomendasi Area Pengelolaan Risiko}

a) Instansi direkomendasikan untuk mempunyai program kerja pengelolaan risiko keamanan informasi yang terdokumentasi dan secara resmi digunakan diterapkan secara menyeluruh.

b) Instansi direkomendasikan untuk menetapkan penanggung jawab manajemen risiko dan eskalasi pelaporan status pengelolaan risiko keamanan informasi sampai ke tingkat pimpinan diterapkan secara menyeluruh.

c) Instansi direkomendasikan untuk mempunyai kerangka kerja pengelolaan risiko keamanan informasi yang terdokumentasi dan secara resmi digunakan diterapakan secara menyeluruh.

d) Kerangka kerja pegelolaan risiko direkomendasikan untuk mencakup definisi dan hubungan tingkat klasifikasi aset informasi, tingkat ancaman, kemungkinan terjadinya ancaman tersebut dan dampak kerugian terhadap Instansi telah dalam penerapan atau diterapkan sebagian.

e) Profil risiko berikut bentuk mitigasinya direkomendasikan untuk dikaji ulang secara berkala untuk memastikan akurasi dan validitasnya, termasuk merevisi profil tersebut apabila ada perubahan kondisi yang signifikan atau keperluan penerapan bentuk pengamanan baru telah diterapkan secara menyeluruh

\section{2) Rekomendasi Area Aspek Teknologi}

a) Adanya standar dalam menggunakan enkripsi diterapkan secara menyeluruh.

b) Perusahaan menerapkan pengamanan untuk mengelola kunci enkripsi (termasuk sertifikat elektronik) yang digunakan, termasuk siklus penggunaannya diterapkan secara menyeluruh. 
c) Sistem dan aplikasi secara otomatis mendukung dan menerapkan penggantian password secara otomatis, termasuk menon-aktifkan password, mengatur kompleksitas password dan penggunaan kembali password lama diterapkan secara menyeluruh.

d) Akses yang digunakan untuk mengelola sistem (administrasi sistem) menggunakan bentuk pengamanan khusus yang berlapis diterapkan secara menyeluruh.

Adanya laporan penyerangan virus/malware yang gagal/sukses ditindak lanjuti dan diselesaikan yang telah diterapkan secara menyeluruh.

\section{KESIMPULAN}

Kesimpulan yang dapat diambil dari hasil penelitian dan pembahasan yang telah dilakukan pada Sistem Informasi Human Resoruces Management Systems pada PT MMC Metal Fabrication antara lain (1). Sistem Informasi Human Resources Management System memperoleh hasil akhir "Cukup" (hasil akhir didapat dari ketentuan status kesiapan berdasarkan kategori sistem elektronik) dengan total skor akhir adalah 480 dari 645 poin maksimal. Pada Kategori Sistem Elektronik memperoleh kategori "Tinggi" dengan memperoleh skor 22 dari 50 poin maksimal. Pada Area Tata Kelola dan Area Pengelolaan Aset memperoleh tingkat kematangan III dan pada Area Pengelolaan Risiko, Area Kerangka Kerja dan Area Teknologi memperoleh tingkat kematangan II. (2). Untuk memaksimalkan proses bisnis dari Sistem Informasi Human Resources Management System maka dibutuhkan peningkatan pada Area Risiko sebesar 8 skor tambahan dan pada Area Teknologi sebesar 10 skor tambahan sesuai dengan Rekomendasi Hasil Evaluasi SI. (3). Dari hasil pengolahan dan temuan pada Evaluasi Sistem Informasi Human Resources Management System maka direkomendasikan peningkatan pada Area Pengelolaan Risiko dan Area Teknologi.

\section{UCAPAN TERIMA KASIH}

Kami ucapkan terima kasih yang sebesar-besarnya kepada semua pihak yang turu berpartisipasi dalam proses penelitian ini, terutama Kepala HRIS PT MMC Metal Fabrication Bekasi beserta staf dan juga Kepala IT Department PT MMC Metal Fabrication Bekasi beserta staf.

\section{REFERENCES}

[1] K. A. Astiti, Evaluasi Pembelajaran. Yogyakarta: Penerbit Andi, 2017.

[2] G. M. Marakas and J. A. O’Brien, Pengantas Sistem Informasi. Jakarta: Salemba Empat, 2017.

[3] Badan Siber dan Sandi Negara, "Indeks Keamanan Informasi (KAMI)," 2015. .

[4] S. Indah, D. Octaviani, and A. D. Herlambang, "Evaluasi Kesiapan Kerangka Kerja Keamanan Informasi Pada Dinas Komunikasi Dan Informatika Kota Batu Dengan Menggunakan Indeks KAMI," J. Pengemb. Teknol. Inf. dan Ilmu Komput., vol. 3, no. 3, pp. 2741-2745, 2019.

[5] P. D. A. Pamungkas, "ISO 9126 Untuk Pengujian Kualitas Aplikasi Perpustakaan Senayan Library Management System (SLiMS)," J. RESTI, vol. 2, no. 2, pp. 465-471, 2018.

[6] F. A. Basyarahil, H. M. Astuti, and B. C. Hidayanto, "Evaluasi Manajemen Keamanan Informasi Menggunakan Indeks Keamanan Informasi (KAMI) Berdasarkan ISO/IEC 27001:2013 Pada Direktorat Pengembangan Teknologi Dan Sistem Informasi (DPTSI) ITS Surabaya," J. Tek. ITS, vol. 6, no. 1, p. 227, 2017.

[7] R. Tullah and M. I. Hanafri, "Evaluasi Penerapan Sistem Informasi Pada Politeknik LP3I Jakarta Dengan Metode Pieces," J. SISFOTEK Glob., vol. 4, no. 1, pp. 22-28, 2014.

[8] H. Basri, M. Suyanto, and M. R. Arief, "EVALUASI IMPLEMENTASI SISTEM INFORMASI MANAJEMEN HOTEL TERHADAP PERENCANAAN STRATEGI PERUSAHAAN (Studi Kasus Sistem Informasi Fidelio Pada Hotel Wisanti Yogyakarta),” J. Teknol. Inf., vol. VII, pp. 79-96, 2013 